\title{
9. New trends in financing civil litigation in Europe: lessons to be learned
}

\author{
Mark Tuil and Louis Visscher
}

\section{INTRODUCTION ${ }^{1}$}

Civil litigation serves a multitude of goals, many of which were explicitly touched upon in the previous chapters. Civil litigation in the first instance is a way of resolving conflicts. Depending on the type of conflict at hand, the plaintiff for example may want the court to issue a declaration regarding the unlawfulness of the defendant's behaviour, or he may want the defendant to restore the status quo ante, to refrain from further infringements, to perform his contractual duties, to compensate his losses, or to restitute illegitimate benefits. In essence, civil litigation is a way to realise rights and entitlements, without having to resort to vigilantism.

In addition, civil litigation is a driving force behind legal development. The continuous flow of cases forces (or maybe better: enables) courts to find new solutions for existing problems. An ever-changing society is confronted with conflicts which legislators cannot all foresee ex ante. However, the ex post character of civil litigation enables courts to seek solutions to the arisen issues.

Furthermore, even though the conflict resolving goal of civil litigation in essence is retrospective to the conflict at hand, the legal norms which are created by the courts in deciding the cases may very well have an ex ante impact on the parties involved in the conflict, as well as on other actors. Put differently, civil litigation may also serve the goal of deterrence, because it shows prospective norm violators which sanctions could result from their lawbreaking behaviour. 


\section{THE PROBLEM OF FINANCING CIVIL LITIGATION}

Irrespective of the goals which one ascribes to civil litigation, these goals can only be reached if litigation indeed takes place. However, many obstacles to bringing a civil claim exist. For example, the potential plaintiff may not know that a norm violation has occurred, he may fear that he will not be able to meet the required standard of proof, or he may decide to wait for others to bring a claim so that he can take a free ride on these efforts.

The obstacle that forms the main topic of this Volume consists of the costs of bringing a civil claim. If these costs outweigh the expected benefits of the civil claim to the plaintiff (both costs and benefits may be monetary and/or non-monetary), it is very likely that the potential plaintiff will decide not to bring a claim at all. In economic terms, he remains rationally apathetic (see Chapter 2 by Visscher and Schepens and Chapter 4 by Keske, Renda and Van den Bergh). This problem is exacerbated if a potential plaintiff is risk-averse so that he does not want to run the risk of having to pay high legal fees (possibly including the legal costs of the opposing party, should the plaintiff lose), if the funds for bringing legal claims are limited or in case of widespread, small losses (trifle damage or so-called 'scattered damage').

This financing problem may be combated in many different ways. Two instruments which lie outside the primary scope of this book, are publicly subsidised legal aid and public rather than private enforcement. Cutbacks on legal aid are exactly one of the reasons why the issue of financing civil litigation is becoming more and more important. Besides, as Faure, Fernhout and Philipsen point out it does not provide a solution to the financing problem for the so-called 'sandwich-class', that is the people too wealthy for subsidised legal aid but not wealthy enough to be able to self-finance civil litigation. Public enforcement strictly speaking is no solution to the problem of financing civil litigation, because it removes the need for civil litigation in the first place. It lies beyond the scope of this chapter and Volume to go into details into the reasons why public enforcement is no perfect solution. In many areas of law, public and private enforcement coexist, showing the need for private enforcement and hence the importance of solutions to the financing problem. Even in some settings where public enforcement until now has been the paramount form of enforcement, private enforcement is gaining in importance (see Chapter 4 which deals with private enforcement of competition and consumer law). 


\section{THE POSSIBLE SOLUTIONS DISCUSSED IN THIS VOLUME}

This book focuses on several possible ways to deal with the issue of financing civil litigation, other than subsidised legal aid and public enforcement. Specifically, the following methods are discussed:

- Cost Shifting or Fee Shifting: different ways in which the costs of litigation are divided between plaintiff and defendant are analysed. In this respect a dichotomy is created between the 'American Rule' (where each party bears its own legal expenses) and the 'English Rule' (where the losing party pays the litigation costs of the prevailing party, also called the 'loser-pays-principle'), although it should be noted that in practise most jurisdictions, including the American and English, use a mix between the two extremes. Also other rules, such as 'one way fee shifting' are treated;

- Fee Arrangements: in many of the chapters in this book, the issue of lawyer's fees appears. Hourly fees, contingency fees and conditional fee arrangements all influence the costs to the plaintiff of bringing a civil claim. Especially 'no cure, no pay' or 'no win, less fee' arrangements may reduce the hurdle of bringing a civil claim. However, fee arrangements turn out to affect much more than only the costs of bringing the claim, as is shown in several contributions;

- Legal Expense Insurance: Before-the event insurance (BTE) and After-the-event insurance (ATE) reduce the financial burden of civil litigation to the parties involved. Especially in Chapter 5 of Van Boom analyses the strengths and weaknesses of these instruments in overcoming the financing problem;

- Group Litigation: in Chapter 4 of Keske, Renda and Van den Bergh discuss a different approach to the financing problem: group litigation. In essence, through sharing (some of) the costs of litigation by bringing similar cases collectively in one procedure, the costs per plaintiff dramatically decrease, which reduces rational apathy. However, other problems such as principal-agent problems between the lawyer and the represented parties may occur and obviously, the collective claim has to be financed. Hence, the topics of cost shifting, fee arrangements and legal expense insurance are also relevant in a setting of group litigation;

- Public Funds: Keske, Renda and Van den Bergh as well as Faure, Fernhout and Philipsen discuss several 'contingency style litigation funds', which cover plaintiffs' costs. Plaintiffs only pay a fee to the fund in case of success, but the fund retains the lawyer on the basis of the existing fee arrangements (often hourly fees); 
- Assignment and Securitization of the Claim: in Chapter 6 of Pinna analyses yet another avenue which could be taken. An injured party could, at least in theory, assign the claim to a third party. The price received can be regarded as his compensation, which he receives even before liability and the extent of the losses have been established by means of litigation. The assignee could securitize the claim, which - again at least in theory - could solve the financing problem.

The chapter in this book target the topic of financing civil litigation from a legal, an empirical and an economic perspective. By combining the three approaches, we believe that a better picture of the financing problem can be painted than by focussing on only one of these perspectives. The economic approach can, on the basis of the assumptions that are made regarding human behaviour, predict the effects of the different instruments on issues such as the level of claims, the quality of the claims, the duration of trial, the possible misalignment of incentives of plaintiffs, lawyers and/ or insurance companies, et cetera. The empirical approach can provide valuable information on which instruments are actually used in practice, test the theoretical hypotheses derived from the economic theory, and indicate the relative size of the predicted, sometimes opposing, effects. The legal approach can show which instruments are actually available and can expose relevant legal differences between the various forms of the instruments, which from a non-legal perspective may look the same at first glance. It can also show the purpose of a rule and the principle on which the rule is based and thus indicate the 'no-go-areas'.

Besides the contributions of European authors, which discuss the new trends that are visible in Europe, Hensler provides an American perspective on the topic of financing civil litigation. This is especially important as in European discussions regarding aspects of civil litigation, for example, contingency fees or class actions, the 'American situation' is being used as an example of how not to proceed. Hensler's contribution shows that the fear for the 'American situation' is often ill-founded.

The fact that the goals of civil litigation can only be reached if financing problems are overcome shows the societal importance of analyzing the potential solutions. This holds even more now private enforcement is becoming more important in the European context, and the budgets available for subsidised legal aid become tighter. In Chapter 7 Fenn and Rickman explicitly deal with empirical research regarding the relationship between a decrease in public funding and an increase in other solutions to the financing problem, such as conditional fee arrangements.

As becomes apparent from several chapters in this book, the instruments under discussion may provide an additional benefit besides improving 
access to justice. They may also entail a selection effect towards higher quality claims, which would result in especially more meritorious claims being brought. The way in which the various instruments influence access to justice, quality of the claims, the interplay between the parties involved et cetera, will be subsequently discussed in more detail below.

\section{COST SHIFTING}

Cost shifting, also called 'fee shifting' (but we use the term cost shifting to avoid confusion with the alternative instrument of 'fee arrangements') considers the question of which party bears which legal costs. Under the American rule each party bears its own costs, while under the English Rule the costs are shifted to the losing party. In practise, there is a 'gray area' between the American and the English Rule, now often not all costs are shifted under the English Rule (see also Pinna), for example because they are regarded as excessive (also see the judgment of the European Court of Human Rights from December 15, 2009, in the case Financial Times Ltd and others $v$. the United Kingdom). ${ }^{2}$

Visscher and Schepens describe the effects of cost shifting on the basis of a review of mostly theoretical literature. Whether the level of suit will increase under the English Rule as compared to the American Rule depends among others on the assessment of the plaintiff of his chances to win (in which case he does not bear his litigation costs) and on his degree of risk aversion (under the English Rule risk-averse plaintiffs will sue less often, given that the stakes now also include the litigation costs. Van Boom discusses the way in which after the event insurance in a sense forces the losing party to finance the risk aversion of the winning party, now he also has to reimburse the insurance premium). The fact that losing plaintiffs under the English Rule have to bear all litigation costs in theory discourages potential plaintiffs to bring weak claims, while the fact that winning plaintiffs do not bear any litigation costs stimulates bringing high-quality claims. The existing, albeit limited, empirical research seems to corroborate this hypothesis. Cost shifting therefore could be regarded as an instrument which lowers the financing problem, especially for meritorious claims. However, the overall effect of cost shifting measures also strongly depends on the fee arrangement in place.

With regards to group litigation, Keske, Renda and Van den Bergh argue that the English Rule may hinder this form of litigation due to the increased risk it entails. They doubt, however, that a shift to the American Rule would lead to more representative actions being brought by, for example, consumer associations, because the decision of whether or not 
to sue does not only depend on the costs, but more importantly on the expected benefits. They also argue that the increased risk caused by the English Rule in group litigation may be mitigated by the use of contingency fees or conditional fee arrangements, because such an arrangement shifts the risk from the plaintiff to his lawyer. One-way fee shifting would encourage litigation even more in a setting of contingency fees, because if the case is won, the losing party pays the litigation costs, and if the case is lost, due to the contingency fee the plaintiff(s) pay(s) nothing anyway.

\section{FEE ARRANGEMENTS}

Many chapters in this book devote attention to the payment structure of lawyers. Legal fees form a substantial part of the costs of civil litigation and hence of the financing problems. Under hourly fees, the lawyer has to be paid on the basis of the time he has spent on the case, irrespective of the outcome. This may form a substantial hurdle to civil litigation being brought. However, arrangements that link the payment to the outcome of the result could overcome this hurdle.

This book illustrates the need for clear definitions. Faure, Fernhout and Philipsen analyse the main forms of fee arrangements. 'Contingency fees' are a combination of 'no cure, no pay' and quota pars litis. Hence, if the case is lost the lawyer is not paid, and if the case is won the lawyer receives a percentage of the proceeds. A 'conditional fee arrangement' (CFA) in their definition entails that a losing lawyer receives nothing while a winning lawyer receives a success fee (a flat fee or an additional percentage on top of the regular fee). Some of the other contributions in this Volume apply the same concept. Keske, Renda and Van den Bergh, however, define a CFA as an arrangement where a losing lawyer only receives his basic fee while a winning lawyer also receives the success fee. This shows the need for clear definitions, because the conclusions reached by these authors when comparing contingency fees with CFA are strongly influenced by their definition of CFA. We do not argue here that one definition is better than the other, but as Faure, Fernhout and Philipsen rightfully state, 'the rather liberal use of concepts such as 'contingency fees', 'no cure no pay', 'no win no fee' and 'success fees' may give rise to many misunderstandings', which would cloud the already complicated debate. The last form of fee arrangements which Faure, Fernhout and Philipsen distinguish is the 'Dutch agreement', which is a combination of 'no win, less fee' and either quota pars litis or an unrestricted success fee. In our view, the CFA of Keske, Renda and Van den Bergh forms an example of such a 'Dutch agreement'.

Contingency fees reduce the financing problem, because a losing 
plaintiff bears no litigation costs, while a winning plaintiff finances these costs out of the proceeds of the claim. ${ }^{3}$ In a sense, the lawyer pre-finances and insures these costs so that (especially risk averse) plaintiffs may bring suit where they would not have done so under hourly fees. The hourly wages of contingency fee lawyers will be higher than those of hourly fee lawyers because the former will charge a premium for their financing and insurance service. Fenn and Rickman indeed find empirically that under result-based fees, the plaintiff's net reward is lower than under hourly fees. Hensler shows that many victims in personal injury cases prefer contingency fees over hourly fees or flat fees despite the lower reward. Whether the improved access to justice due to result-based fees leads to an increase in the level of suits depends on many factors, such as the impact of the threat of litigation on the behaviour of actors and, very importantly, on the role of lawyers as gatekeepers. After all, lawyers receive incentives to better screen the cases which they are willing to take, because their remuneration depends on winning the case (see Visscher and Schepens, Faure, Fernhout and Philipsen, Keske, Renda and Van den Bergh, Fenn and Rickman and Hensler). This gate-keeping role has the potential to increase the fraction of high-merit cases, so that result-based fees increase access to justice especially for meritorious claims. Empirical research verifies this gate-keeping role, but it also shows that cases with a relative low value are often turned down. The fear of a flood of litigation and for many meritless cases being brought seems unwarranted, both from a theoretical and an empirical perspective. The contributions of Faure, Fernhout and Philipsen and Hensler show that many forms of result-based fees are applied on both sides of the Atlantic, without any of the alleged problems as a result. Fenn and Rickman argue that CFA is becoming more and more important in England and Wales (the countries which they have studied) as legal aid disappears as a result of policy.

Fee arrangements do not only impact the possibilities of financing civil litigation, but they also may impact the incentives provided to the relevant actors in civil litigation. Under an hourly fee system, the payment of the lawyer depends on how many hours he puts in. Under result-based systems, however, it is the result which is decisive for the remuneration. Under the first system, spending more time on the case directly benefits the lawyer (of course, reputational effects and legal ethics may pose limits to this mechanism), while under the second system this is only the case if the additional efforts are made up for by a better outcome. This line of reasoning touches upon the topic of principal-agent problems. Ideally, the interests of lawyers are perfectly aligned with those of his clients and of society. In practise, this is not the case. Under hourly fees, lawyers may put in more hours than is in the interest of their clients and of society. 
Result-based fees reduce this problem and better align the interests of lawyer and client, because both now have an interest in winning the case. This reason, which is an advantage from the point of view of agency theory, is exactly mentioned as a problem in many legal debates regarding the introduction of contingency fees. Faure, Fernhout and Philipsen show that in many European countries where contingency fees are not allowed, mainly or partly on the basis of this argument, other forms of result-based fees are allowed and used, apparently without (major) problems.

Another way in which contingency fees may combat the principal-agent problem is that lawyers may use the fee as a way to signal their quality (Visscher and Schepens, Faure, Fernhout and Philipsen, Keske, Renda and Van den Bergh). Hensler however states that there is little evidence that lawyers indeed compete through their fee and that only in high-value aviation accident litigation is there evidence of price competition between lawyers.

Result-based fees, however, do not perfectly address the principal-agent problems. Where hourly fees may lead a lawyer to spend too much time on a case, contingency fees may result in the opposite problem. After all, the lawyer bears the full costs of additional efforts, but only receives a percentage of the additional benefits (Visscher and Schepens, Faure, Fernhout and Philipsen). In addition, under the assumption that a lawyer can better assess the quality of a case than the client (especially if the latter is a one-shotter), lawyers may negotiate a too-high percentage when taking a case on a contingency fee basis, or they may give biased advice regarding the decision of the client to opt for hourly fees or contingency fees. Furthermore, the fee arrangement may impact the incentives to settle. Theoretically it can be argued that contingency fees lead to more and earlier settlements than hourly fees, because the lawyer secures his fee with fewer efforts. However, literature that includes lawyer's efforts in the analysis argues that contingency fees on the opposite lead to fewer settlements, because lawyers spend less time on the case during trial. Rejecting settlement offers can also be a strategic move: by signalling confidence in the case if it were to go to trial, a lawyer may extract a better settlement offer in subsequent rounds. Empirical research seems to corroborate the finding that contingency fees lead to fewer settlements (for higher amounts) than hourly fees, and that limitations on contingency fees decrease the probability that a case proceeds to trial. However, Fenn and Rickman also discuss empirical research which shows the opposite result. As Faure, Fernhout and Philipsen state, more empirical research is needed to yield more definite answers. They do recognise the problem, which is also mentioned by Fenn and Rickman, that it may be hard to acquire the necessary data for this. 


\section{LEGAL EXPENSE INSURANCE}

In Chapter 5 Van Boom focuses on legal expense insurance, both in the form of 'Before the event insurance' (BTE) and 'After the event insurance' (ATE). These forms of insurance may overcome the financing problem, because the insurance company now bears the risk of having to bear legal expenses. Under BTE a risk-averse actor purchases insurance against legal expenses he may have to bear if he would become involved in a conflict. Under ATE, policy is concluded after a conflict has occurred which will likely lead to litigation. Van Boom describes how the development of legal expense insurance depends heavily on domestic institutional factors, such as the extent of publicly funded legal aid (also see Fenn and Rickman) and the intensity of regulation of legal services. Also the rules on cost shifting, fee arrangements (Faure, Fernhout and Philipsen describe for several countries how the availability of legal expense insurance affects the development of result-based fees) as well as cultural factors are relevant.

Because BTE solves the financing problem and covers the risk of having to bear large costs, one may expect an increase in the number of suits. This holds even more now through adverse selection mainly high-risk actors would take out insurance and they may exhibit moral hazard so that more conflicts may arise. However, the insurance industry seems quite able to limit these effects. Moreover, insurers may function as gatekeepers, screening the cases on their merits, so that predominantly meritorious claims would be covered. There is no clear empirical support for this theoretical possibility (Visscher and Schepens).

Just as with fee arrangements, the interests of all parties involved may not be perfectly aligned, leading again to principal-agent problems. Van Boom discusses the European Directive on legal expense insurance, which tries to neutralise potential conflicts of interest between insured and insurer, which calls for implementation of arbitration or ADR procedures to quickly settle such conflicts, and which requires a free choice of council. The extent to which insurers are able to keep the costs of litigation low, depends among other factors on whether they can have in-house lawyers or whether they need to retain external lawyers. The difference in financing (the insurer has already received the benefits through the premium and now wants to limit the costs, whereas the remuneration of an external lawyer may depend on the number of hours put in or the result achieved) provides different behavioural incentives, with all the agency problems that come along. Van Boom therefore argues that the free choice of council should be reconsidered. Also the interests of the insurer and the insured may be opposed. The insured may want to litigate more (also the lower quality claims) and settle less (because trial costs are covered) 
and for higher amounts (because the threat to go to trial is more credible). The insurer can try to limit these problems by using deductibles, merit tests, maximum coverage, et cetera (Visscher and Schepens). Fenn and Rickman mention that settlement delay in England and Wales was lower under BTE than under other forms of litigation funding, which suggests that indeed insurers are successful in countering principal-agent problems.

Van Boom distinguishes two forms of ATE arrangements: ATE funding and ATE insurance. ATE funding, also called 'third party funding', means that the provider finances all costs involved in the claim against a 'premium' (varying with the value of the claim and the stage at which the dispute is ended) which is only paid if the case is won. The provider investigates the merits of the claim and only finances viable claims. It is especially used for commercial claimants with high value claims with a high probability of success. Given these characteristics, Van Boom argues that ATE funding looks more like contingency fees than like insurance.

The combination of ATE insurance and CFA results in an instrument which is very beneficial to claimants (also see Fenn and Rickman on this combination). Due to CFA, a losing defendant does not have to pay his own legal costs, but due to the English Rule he does have to pay the legal costs of the prevailing party. The ATE insurance covers those costs. If the claimant wins, he can recover both his legal costs (which due to the CFA success fee may be substantial) and his ATE insurance premium from the defendant. Hence, losing defendants also bear the costs which risk-averse plaintiffs make to cover their risk. The only thing a plaintiff may lose is his ATE insurance premium if he loses. Van Boom describes a recent development which even removes this last risk: a self-insured deferred premium. The premium is only paid if the case is won, and it is then paid by the losing defendant. This instrument induces lawyers and insurers only to take cases on this basis if there is a large enough probability of success. The defendant may receive a (too?) large incentive to settle such cases, given the large financial consequences of losing in court. Therefore, this instrument, although it is very able to overcome the financing problem, may come at the cost of excessive litigation and over deterrence.

\section{GROUP LITIGATION}

Keske, Renda and Van den Bergh discuss the possibilities to ameliorate the financing problems through the use of several forms of group litigation, which is especially relevant in cases of scattered damage (where the problems of rational apathy and asymmetric information play an 
important role). In group litigation, either an informed individual party or an association initiates the proceeding. The superior information, as compared to that of uninformed individuals, tackles the asymmetric information. Rational apathy is addressed because it is no longer an individual victim with relatively low losses as compared to the costs of litigation who has to start the suit. The costs are either divided among more plaintiffs, or borne by for example a representative organization.

If group litigation in the form of a collective action or class action takes place, the extent to which rational apathy is solved depends on the way in which the collective is formed. Under an opt-in regime the problem may persist, because individuals have to become active in order to join the group. Under opt-out and mandatory forms, rational apathy is better overcome. An often-heard resistance against opt-out and mandatory collective actions is that it would deprive individuals from 'their day in court', so it would frustrate access to (individual) justice. In our view it is important to realise that in many instances the problem of rational apathy would avoid most individuals from bringing a claim anyway so that this argument is often an empty shell. Collective actions in a sense increase access to justice rather than frustrate it because as a member of the group, the individual victim may receive some compensation where individually he would not have brought a claim. And even if the individual would not receive individual compensation, for example because a $c y$ pres system is applied, the possibility of collective claims may provide deterrent incentives to potential wrongdoers so that potential victims still benefit from reduced risks.

A drawback of group litigation may be that it introduces several forms of principal-agent problems. A representative organization or a lawyer litigating on behalf of a group of victims may have different interests at heart than the victims themselves. Especially in cases where the value of each individual claim is limited, victims will not spend much effort on monitoring the agent. Keske, Renda and Van den Bergh give examples of class action settlements which are rather beneficial to the lawyers and/or the defendant, but not so much for the plaintiffs, for example the so-called coupon settlements (also see Hensler on this issue). In Section 5 above it already became clear that fee arrangements may influence the agency problems. This holds even more in group litigation, now the plaintiffs have fewer incentives to monitor their representative. Hensler discusses Rule 23 of the Federal Rules of Civil Procedure, which contains instruments to combat agency problems (such as the requirement that the class is adequately represented and that proposed settlements have to be approved by the court).

The possibility of group litigation may also lead to frivolous suits: low 
(or even 'no') quality claims being brought in order to distract a settlement, because for the defendant settlement may be cheaper than trial (especially when potential reputational effects are incorporated), even in case of success.

Representative actions by, for example, consumer associations in the view of Keske, Renda and Van den Bergh do not solve the financing problem as good as class actions (which are almost always combined with contingency fees). The association's budget may not be large enough to finance the desired amount of litigation. Government funding could improve the situation, but also public budgets are limited. Furthermore, public funding may make the association too dependant on the government. Given the remaining financing problems, Keske, Renda and Van den Bergh advocate introduction of result-based fees. They also argue that agency problems may not be solved by representative actions, because the association may very well have interests which depart from those of the consumers at large. They suggest that agency problems are better solvable under collective actions financed via contingency fees. Due to the characteristics of collective litigation, result-based fees stimulate collective litigation even more than individual litigation, so that it is a powerful tool to overcome the financing problem.

\section{PUBLIC FUNDS}

Faure, Fernhout and Philipsen, as well as Keske, Renda and Van den Bergh give their attention to yet another way of financing civil litigation: contingency-style public funds. For example in Hong Kong, the Supplementary Legal Aid Scheme (SLAS) after a merit test may take on a case on a contingency fee basis. Hence, the fund pays all costs and the plaintiff only pays a contribution to the fund if he prevails. The lawyers, however, are paid by the fund on the basis of hourly fees. The fund, being a repeat player, is better able to monitor the lawyers than one-shot plaintiffs would be, so that this solution may reap the fruits of contingency fees (financing civil litigation, especially for the sandwich class) while avoiding the agency problems that normally come along.

Keske, Renda and Van den Bergh argue that the success of such funds depends, among others, on the design of the fund (for example the percentage to be paid in case of success and the formalities involved in applying) and on the cost shifting rules which are in place. They describe a successful Canadian fund as well as less successful Canadian and Australian funds. The SLAS discussed by Faure, Fernhout and Philipsen also seems successful in addressing the problem of financing civil litigation. 


\section{ASSIGNMENT AND SECURITIZATION}

Pinna discusses the possibility of transferring one's claim to a third party. This way the victim receives an amount of money (the price paid be the assignee) even before any litigation has commenced. In a sense this is therefore no solution to the financing problem as a whole, but it removes the financing problem for the potential claimant altogether, because he does not bring the claim anymore. The price would depend on the value of the claim, the probability of success, the expected legal fees and a risk premium and it accounts for the time difference between the payment of the price and the outcome of the trial. The price would hence be lower than the losses of the victim, but the latter does not run a risk and bears no costs. It may therefore be an attractive scheme for victims who prefer receiving a lower amount now over the possibility of a higher amount later.

Pinna discusses potential legal hurdles regarding assignment of claims, such as the English prohibition of assignment of 'mere rights of action'. $\mathrm{He}$ also shows that assignment of the proceeds of the claim is allowed under tort law (Hensler discusses some American examples of this idea), and under contract law assignment is allowed if the assignee has a genuine commercial interest. In France assignment is allowed, but if this is done after the claim is already brought to court, the defendant can extinguish the claim by refunding the assignee the price he paid for the claim. This greatly limits the possibilities for securitization, so the possibility for the assignee to sell his claim to another party, either through a succession of assignments or by setting up a special purpose investment vehicle.

The advantages of assignment in Pinna's view are manifold. First, the injured party receives compensation quickly, without costs and risk. Second, it may benefit the assignee because he regards it as an investment. Differences in risk attitude between the victim and the investor, as well as differences in time preference and access to capital can make assignment attractive to both. Third, it could accommodate group litigation in jurisdictions which do not allow class actions. Even where they are allowed, assignment introduces less severe agency problems than class actions, provides higher awards for the victims and avoids the strict conditions surrounding class actions.

The main disadvantage according to Pinna is that assignment is only possible on a voluntary basis. In our view, the fact that the victim will never receive full compensation should be mentioned as a potential problem. Of course, in other situations where the plaintiff bears litigation costs himself he is also not fully compensated, but instruments such as legal expense insurance or cost shifting could be more attractive to plaintiffs. Another 
problem which is not discussed by Pinna is the fact that the assignee, when bringing the case to court, may have to obtain information from the victim in order to, for instance, meet the burden of proof. The fact that the victim has already received his money may make him less inclined to spend time and other resources on the case.

\section{LESSONS TO BE LEARNED}

Financing civil litigation is a topic which appears to have a much broader impact than merely the question of how to finance the costs of civil litigation. In various contributions to this Volume it became clear that the separate instruments may not only affect access to justice, but also the quality of the claims that are being brought, the behaviour of plaintiffs, defendants and legal representatives in settlement negotiations and during trial, as well as possibly the behaviour of parties before conflicts have arisen.

The complexity of the analysis further increases if one realises that many instruments are used in various combinations. Keske, Renda and Van den Bergh have given explicit attention to the differences between class actions and representative actions when combined with contingency fees or CFA, under various cost-shifting rules. Faure, Fernhout and Philipsen analyse the SLAS, which combines public funding with result-based fees. Van Boom discusses the potential pitfalls of the combination of ATE and CFA. Fenn and Rickman analyse the development in the use of various combinations in England and Wales, especially as a result of declining legal aid.

The theoretical predictions discussed in the contributions are not unambiguous and empirical research is not providing unambiguous results either (due to limited availability of data or differences in methodology). Several authors therefore call for more empirical research in order to better assess the effects of the alternatives schemes.

Notwithstanding the need for additional research, we believe that this book can already contribute to the debate on alternative ways of financing civil litigation in Europe, besides the traditional form of subsidised legal aid. At this place, we would like to isolate two remarkable conclusions, or lessons for the future, which appear from the different contributions.

First, when discussing the financing problem, one should not separate this from the other effects that solutions to the financing problem may have. Especially the potential of fee arrangements, cost shifting rules and insurance schemes to screen cases on their quality is an interesting aspect. By improving access to justice especially for meritorious claims, the goals which are served by civil litigation may be better reached. One should, 
however, keep a critical approach to avoid undesirable effects, such as those of the combination of ATE and CFA, discussed by Van Boom.

Secondly, the substantial resistance in Europe against financing instruments in general and against US-style class actions and contingency fees specifically should be replaced by a more positive, open approach to these instruments. Faure, Fernhout and Philipsen show that many forms of result-based fees already exist in several European countries, apparently without causing substantial problems. Visscher and Schepens discuss the theoretical arguments pro and con contingency fees, where the arguments pro seem to outweigh those con. Keske, Renda and Van den Bergh argue that especially for scattered losses, class actions and contingency fees may be exactly what we need in order to enable effective private enforcement in the first place. The overall picture which emerges therefore is that allowing contingency fees is Europe as a way to secure access to justice should be seriously considered.

This development should not be rejected with a simple reference to 'the American situation', because, as is shown by Hensler's contribution, much of the resistance to this alleged situation is based on a misunderstanding or an incomplete assessment of this situation. Similarly, a reference to the traditional legal opposition on the bases of arguments such as that the lawyer should not have an own interest in winning the case or that contingency fees cause a flood of litigation, under-appreciates or even neglects the theoretical arguments in favour of contingency fees, the empirical research which seems to corroborate the theoretical findings and the fact that the system of hourly fees may cause principal-agent itself, which could be more serious than those of a contingency fee system. We therefore feel that those who still want to reject the instruments that have been discussed in this book have to provide ample reasons for their position.

This does, however, not mean that we advocate an unrestricted introduction of these instruments. First of all, as has become apparent, the effect of the introduction of these instruments depends on other rules regarding litigation costs, the availability of other instruments and legal culture. We therefore feel that the instruments should only be introduced after a careful legal and economic analysis of their potential effects and subsequential empirical research. Similarly, we do advocate that existing instruments are carefully scrutinized and in the case where these instruments seem to be particularly problematic, these instruments could be further regulated or in extreme cases banned. Some forms of the CFA + ATE contracts reported on by Van Boom could serve as a good example.

This book does not solve all problems and does not answer all questions. We do think that, by combining legal, empirical and economic approaches, it has provided new insights and arguments in the legal debate 
regarding financing civil litigation. By doing this, it has also shown the direction in which future research could (or maybe: should) go. In other words, it shows New Horizons in Law and Economics of civil litigation: more legal research into the peculiarities of existing and newly developing instrument to finance civil litigation, more (theoretical) economic research to derive hypotheses about the way in which these instruments influence human behaviour, and more empirical research to test those hypotheses in practice.

\section{NOTES}

1. The authors would like to thank Michael Faure for his concluding remarks at the Conference, which were very useful for this chapter.

2. Application no. 821/03.

3. Other forms of result-based fees also have the potential of reducing the financing problem, although less distinct in a case where a losing plaintiff still bears some costs. 